\title{
OCCURRENCES OF MINERAL RESOURCES IN BANDIPUR-GONDRANG AREA OF TANAHUN DISTRICT, CENTRAL NEPAL, LESSER HIMALAYA
}

\author{
Kabiraj Paudyal
}

\author{
Central Department of Geology, Tribhuvan University, Kirtipur, Kathmandu, Nepal
}

\begin{abstract}
A detailed geological investigation was carried out to assess the distribution of minerals and their geological control in Bandipur-Gondrang area of Tanahu district, a part of Lesser Himalaya in central Nepal. The area is found rich in both metallic and non-metallic mineral deposits. The main metallic minerals found are iron in Phalamdada and Labdi Khola, copper in Bhut Khola and poly-metallic deposits including suspected gold in Bhangeri Khola and Jaubari Khola-Bar Khola sections. A large deposit of inorganic carbon is found around the Gondrang-Watak area. Similarly, a good quality of green marble (metabasite) is found as decorative stone in Bagar Khola area and good quality of roofing stone in Bandipur area. In addition to these economic deposits other several sub economic to non-economic mineral are also located in the geological map of the area. Categorization of these mineral deposits is based on the probable reserve and laboratory analys is of related samples. Geological control of mineral deposits is considered to be the stratigraphic, structural, metamorphic and hydrothermal. Iron mineralization of the area is found stratigraphical control, copper deposits by magmatism of basic rocks (amphibolites), and poly-metallic deposits are related to the hydrothermal processes.
\end{abstract}

Keywords: mineral resources, metallic and non-metallic depos its, iron and copper deposits, green marble, polymetallic deposits, geological control, Central Nepal

\section{Introduction}

The study area is a small part of Lesser Himalaya in central Nepal (Fig 1). The area lies between the latitudes of $27^{\circ} 49^{\prime} 45^{\prime \prime} \mathrm{N}$ and $27^{\circ} 55^{\prime} 10^{\prime \prime} \mathrm{N}$ and between longitudes of $84^{\circ} 22^{\prime} 35^{\prime \prime} \mathrm{E}$ and $84^{\circ} 28^{\prime} 30^{\prime \prime} \mathrm{E}$. It lies on the vicinity of Bandipur and Seti Nadi. The topographical maps entitled Dumre-Bandipur (Sheet: 2784 02B) and Jugedi (Sheet: 2784 02D) published by Department of Survey, Government of Nepal include the study area. Tectonic ally, the study area lies near the western closure of the Mahabharat Synclinorium.

\footnotetext{
*Corresponding author: Kabiraj Paudy al

Central Department of Geology, Tribhuvan University, Kirtipur, Kathmandu, Nepal

Email: paudy alkabiraj@y ahoo.com
}

(Received: 2013 Jan 4 Accepted: 2013 Mar 8)

\section{Previous Works}

Many works on mineral deposits of the area have been reported in both published and unpublished reports of Department of Mines and Geology (Sharma, 1990 and 1995; Talalov, 1972; DMG, 2004). Present area was also explored by the team of geologists of the mineral exploration project from the Department of Mines and Geology, Nepal (Stocklin and Bhattarai, 1977; Stocklin, 1980) and by (United Nations, 1993). O' Rourke (1958) has described the occurrences and distribution of Bandipur Slates of the present study area.There is a description of Labdi Khola iron deposits and Bhut Khola copper deposits as economic deposits in addition to a large number of other sub-economic deposits. Then, the works on mineral deposits of the country have been continuously carried out by the 
Department of Mines and Geology. According to the works of DMG, the Bhut Khola Copper Deposit is hosted in the phyllite and quartzite of Kuhchha Group. Quartzite, magnetite, chalcopyrite, and pyrrohotite are the ore minerals found in that area. The copper-cobalt occurs in lenses of 30m thick in Bhut Khola which extends nearly $5 \mathrm{~km}$ along strike with discontinuous lenses (O' Rourke, 1959 and O' Rourke et. al;1959). Similarly, Labdi Iron Deposit of Labdi-Letsar area is hosted in Labdi Phyllite of Kunchha Group (DMG, 2004). Later, Paudyal and Paudel (2011) and Paudyal et.al. (2012) prepared detailed geological map of the area in 1:25,000 scales. Based on their works both the Labdi Khola iron and Bhut Khola copper deposits lie in the Labdi Khola Member of the Nourpul Formation.

\section{Mineral Deposits}

The following mineral deposits are found in the study area:

Phalamdada Iron Deposit: It is located in Phalamdada, south-east to Bandipur (Fig 2).
Stratigraphically, it lies on the top part of the Nourpul Formation and lithologically in between the underlying meta-sediments (phyllite and metasandstone of Nourpul Formation) and the overlying dolomite of Dhading Dolomite. Based on physical properties, it belongs to limonite ore of iron. Physical properties of limonite are: rusting brown color, medium specific gravity, light brown to red streak, spongy in nature, inclusions of phyllite, hackly fracture, metallic luster and opaque. It does not react with dilute hydrochloric acid. Strike length of the strata is measured as $2000 \mathrm{~m}$ with average thickness of $5 \mathrm{~m}$ (Fig 2).

STDS-South Tibetan Detachment System. MCTMain Central Thrust.MBT-Main Boundary Thrust. HFT-Himalay an Frontal Thrust. MT-Mahabharat Thrust. BKF-Bari Gad-Kali Gandaki Fault. PTPhalebas Thrust. MT-Mahabharat Thrust. GKAGorkha-Kunchha Anticlinorium. TS-Tanahu Syncline. KS-Kahau Synclinorium. JS-Jajarkot Synclinorium.

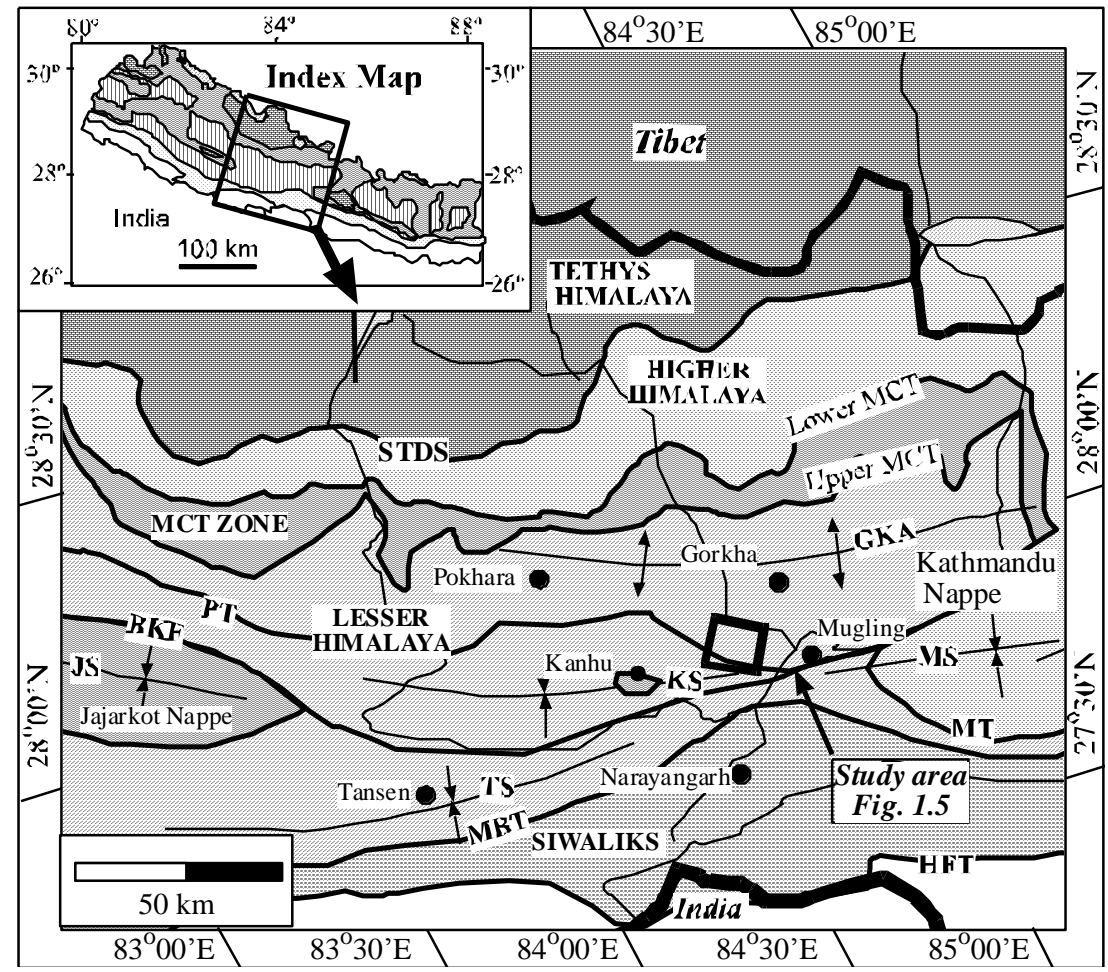

Fig 1 Regional tectonic map of central Nepal Lesser Himalay a (modified after Paudel and Arita, 2000). 


\section{Occurrences of Mineral Resources of Bandipur-Gondrang Area of Tanahun District, Central Nepal, Lesser Himalaya.}

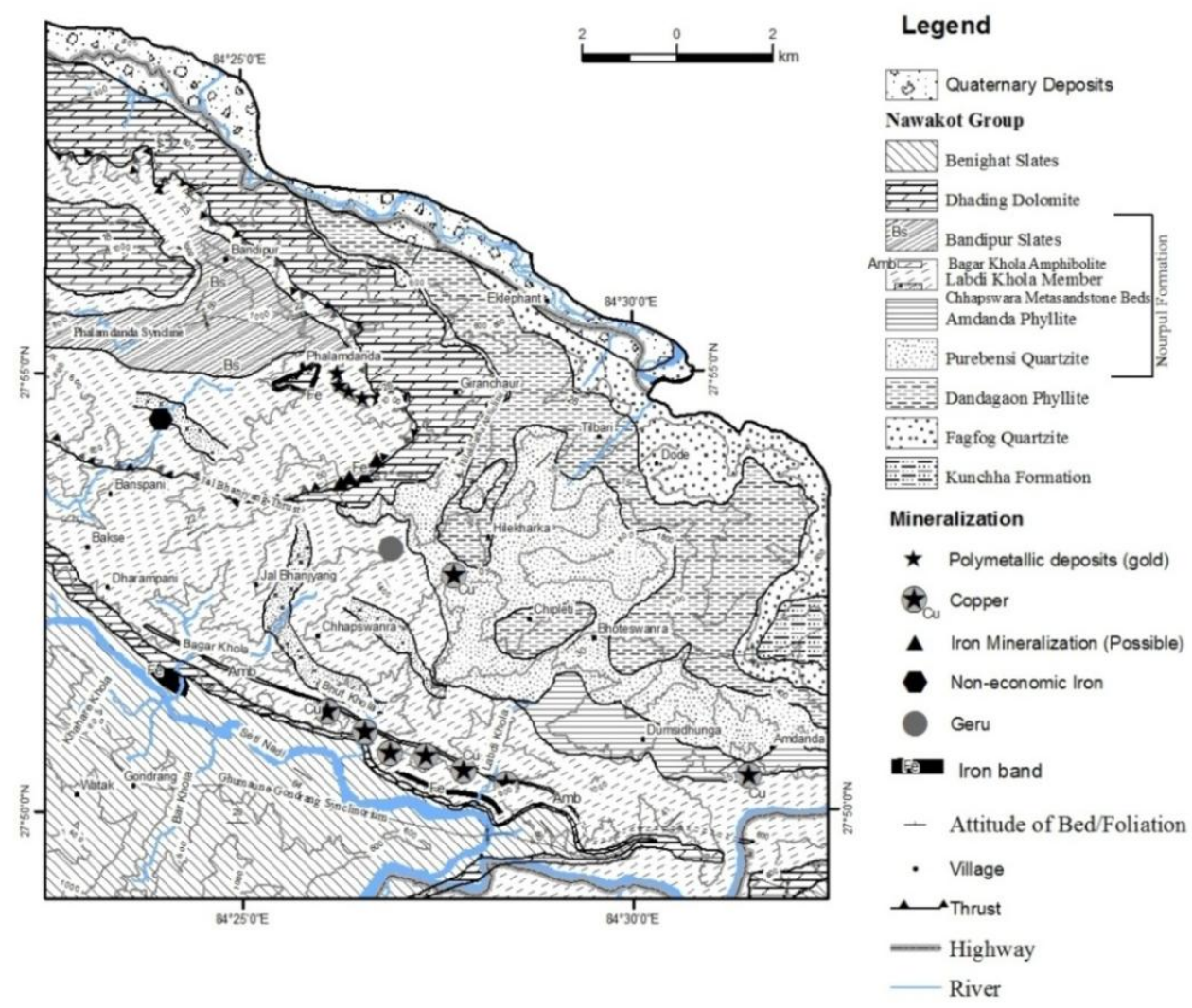

Fig 2 Occurrences of Mineral Resources in Bandipur-Gondrang Area Of Tanahun District, Central Nepal, Lesser Himalaya

The cyclic deposit of the upper part of the Nourpul Formation shows the fluctuation environment of depositional basin. Dolomite contains abundant

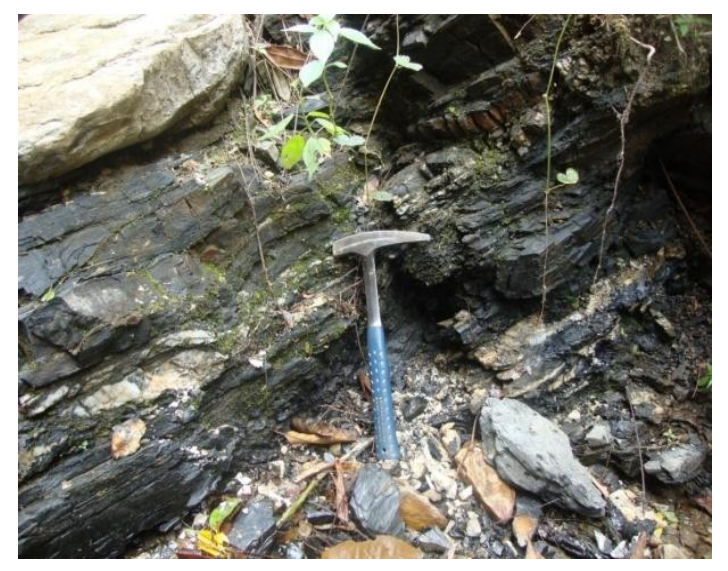

Fig 3 Outcrop view of Bhangeri Khola Poly metallic Deposit, photograph taken at Bhangeri Khola. stromatolites indicating shallow marine depositional basin. Iron deposit in contact between the Nourpul Formation and the Dhading Dolomite conformably represents the sedimentary origin of deposition. Moreover, the iron ore contains abundant phyllite partings. Most probably it was deposited in intermediate depth by precipitation from solution under bacterial action.

Bhangeri Khola Polymetallic Deposit: This deposit is well exposed to the stream section (Bhangeri Khola) between Bhageri and Jhargaun village. One can reach the deposit after moving one hour in local jeep- earthen- road from Bandipur towards Hillekharka (Fig 2). Lithologically, black graphitic phyllite of Nourpul Formation with abundant quartz veins consists of the metallic deposit of pyrite, chalcopyrite, arsenopyrite, copper 
and gold. Two types of veins are observed in the deposit. One is measurable in the field or hand samples ranging from $1 \mathrm{~mm}$ to $3.5 \mathrm{~cm}$ and the other is microscopic. Both veins are rich in polymetallic deposits. The approximate volume of veins is $30 \%$. The horizon is $20 \mathrm{~m}$ thick and has strike length of $1000 \mathrm{~m}$ (not scaled by measuring tape, calculated from map). The outcrop view of host rock bearing poly-metallic minerals is shown in (Fig 3).

Polished section of the vein containing rock sample taken from Bhangeri Khola shows some brilliant fragments without any crystal structure. These fragments are suspected to be gold based on morphological and optical properties. One type of fragment is about $0.03 \mathrm{~mm}$ in size while the other is about $0.003 \mathrm{~mm}$. The rock sample was powdered and treated with concentrated nitric acid properly to assess the presence of gold. After complete reaction with nitric acid, it was washed with distilled water, then it was sundried and examined under binocular microscope (magnification 50). Some suspected golden fragments (size: 0.02 to $0.6 \mathrm{~mm}$ were observed).

Results of the Polished Section The following minerals are observed in the given percentage.

\begin{tabular}{|l|l|}
\hline Mineral & Amount \\
\hline Gold & $<0.1 \%$ \\
\hline Pyrite & $20 \%$ \\
\hline Chalcopyrite & $20 \%$ \\
\hline Arsenopyrite & $10 \%$ \\
\hline Cuprite & $5 \%$ \\
\hline Magnetite & $5 \%$ \\
\hline Carbonaceous Material & $30 \%$ \\
\hline Other Unknown & About $10 \%$ \\
\hline
\end{tabular}

\section{Bhut Khola-Labdi Khola Copper Mineralization:}

The area of mineralization is located at latitude $27^{\circ} 50^{\prime} 55^{\prime}$ ' and longitude $84^{\circ} 26^{\prime} 24^{\prime \prime}$ ' in Toposheet no 2884 02D, Tanahun District (Fig 2). In Bhut Khola area, it lies about $1.5 \mathrm{~km}$ upstream from the confluence of Bhut khola and Seti River. The elevation of the deposit is $390 \mathrm{~m}$ above mean sea level. In Labdi Khola area, the deposit is located at about $1 \mathrm{~km}$ upstream from the confluence of Seti River and Labdi Khola. It is just about $3 \mathrm{~km}$ westw ard from Ghumaune. The Muglin-Narayangar road and the Ghumaune-Damauli Road make it well accessible. Copper mineralized quartzite has been mapped in the area continuously. The mineralized unit is irregular and lensoid in nature. Position of copper mineralization is shown in columnar section of the rocks of the Bhut Khola area (Fig 4). In Bhut Khola area, the mineralized zone is wide whereas in adjacent areas, it is pinching, and thickness is less. Both azurite and malachite minerals are found in Bhut Khola within dirty white to rusting brown quartzite host. Many abandoned past mine adits are present in the area.

Polish section of the rock sample from Bhut Khola is studied. Under plane polarized light, the color of the ore is red brown to brown. Reflectance of the ore is less than pyrite and bireflectance is weak. The sample contains about $2 \%$ copper ore within the field of vision The gypsiferous beds are found in close association with copper mineralization. The gypsum crystals are well developed in the form of radiating ellipses.The extension of Bhut Khola copper mineralization is found extended from Saran in the west to the Labdi Khola in the east during the geological traverse. The nature of mineralization is spotty. By using the result from the ore microscopy, a rough estimation of geological reserve is done. Average strike length of the mineralization: $5 \mathrm{~km}$, average width of the mineralization: $20 \mathrm{~m}$, depth of the mineralization assumed: $50 \mathrm{~m}$, density of the host rock used : 2.5 ton $/ \mathrm{m}^{3}$ estimated geological reserve $=5000 \times 20 \times 50 \times 2.5=12,500,000$ ton, estimated copper reserve $=12,500,000 \times 2 \%=$ 250,000 ton.

Labdi Khola Iron: The Labdi khola iron depos it is located at latitude $27^{\circ} 50^{\prime} 11^{\prime \prime}$ and longitude $84^{0} 27^{\prime} 54^{\prime}$ ' in Toposheet no 2884 02D, Tanahun district. The area lies about $107 \mathrm{~km}$ west from Kathmandu. The elevation of the deposit is $290 \mathrm{~m}$ above mean sea level at Labdi Khola section. The Prithvi Highway, the Ghumaune-Damauli Road, makes it well accessible. 
Labdi Khola is about $3 \mathrm{~km}$ from the Ghumaune. Physical properties of Labdi Khola Hematite are as:

$\begin{array}{ll}\text { Colour : } & \text { Dark Grey to black } \\ \text { Streak : } & \text { Cherry Red } \\ \text { Luster : } & \text { Dull to shiny } \\ \text { Cleavage : } & \text { Absent } \\ \text { Hardness : } & 5 \\ \text { Specific Gravity : } & \text { High }\end{array}$

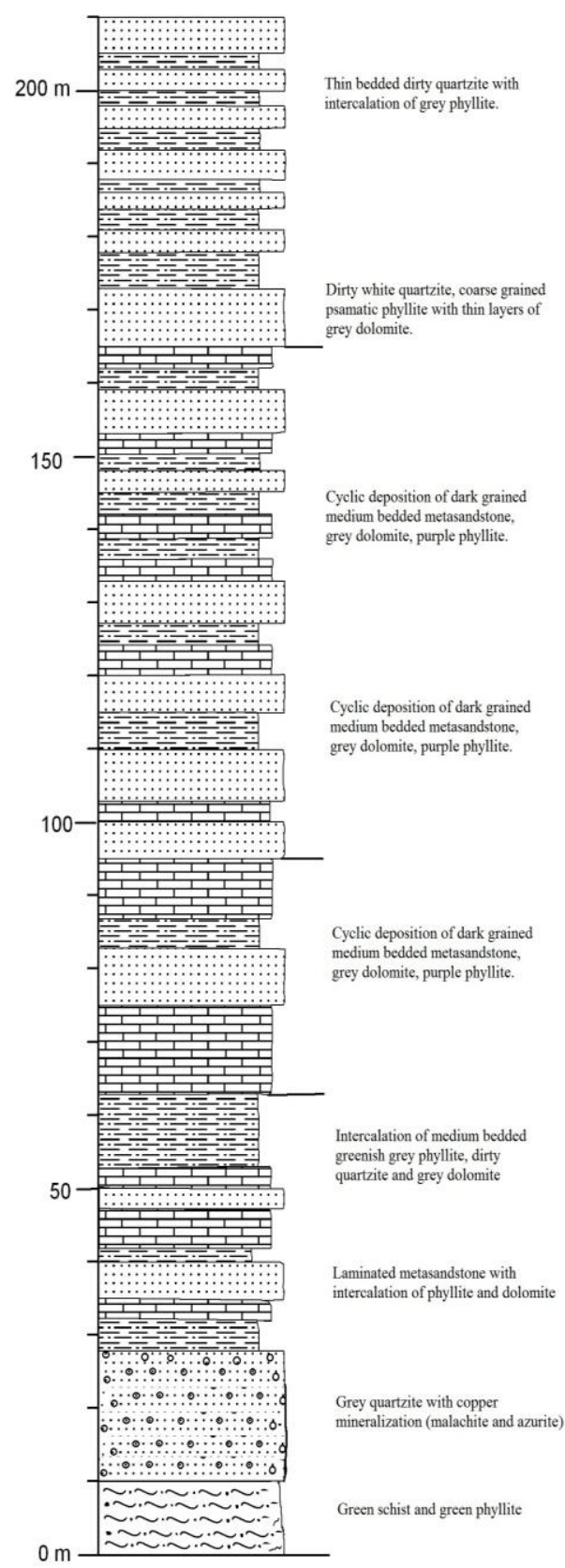

Fig 4 Colu mnar section of the Labdi Khola Member of the Nourpul formation observed in Bhut Khola section showing the position of copper mineralization.
The exposure consists of succession of interbedding of dolomite and phyllite in 1:2 ratio with subordinates of grey metasandstone, and hematite is found conformably within the phyllites (Fig 5). The total thickness of the hematite bands is measured as about $5 \mathrm{~m}$, out of which $1.65 \mathrm{~m}$ and $1 \mathrm{~m}$ thick bands are found more pure with high specific gravity whereas the remaining thickness is calculated within the intercalation of grey phyllite. The ore body seems faint lineations of pelitic minerals. Its streak is cherry red, hackly fracture and brittle in nature.

Samples were studied under both plane polarized light and cross polarized light. The ore mineral is identified as hematite. Under crossed polarized light hematite shows blood red internal reflection while in plane polarized light it is silver white with bluish tints. The grains are intergrow th lens like in lamellae with annealing texture. The mineralized grains have cross-cutting relation to soft sediment to phyllite. The genesis of ore in all locations is identified as sedimentary based on the inclusions of pelitic contents within the hematite and its mutual orientation with the host. The assemblage of the ore body is hematite+ pyrite +rock fragments.

Reserve calculation is done only for the Labdi Khola section as :average thickness of the strata $=5$ meters, average strike length of hematite ore $=500$ meters, density of the hematite used $=5 \mathrm{ton} / \mathrm{m}^{3}$, hence rough estimate for the geological reserve for 50 meter depth $=5 \times 500 \times 50 \times 5=625,000$ tons.

Bagarkhola Green Marble Deposit: This Green Marble (amphibolite) has good outcrop at the confluence of Bagarkhola and a stream from the Pipalswara village (Fig 2 and Fig 6). The amphibolite is massive with the following physical properties: green color, granoblastic texture with faint mineral lineation, lineation is due to some acicular minerals like actinolite and tremolite, high specific gravity, no vesic les and inclusions, absence of visible fractures, moderate to deep weathering in ridges, however, fresh in river and road cut sections, does not react with dilute hydrochloric acid etc. 


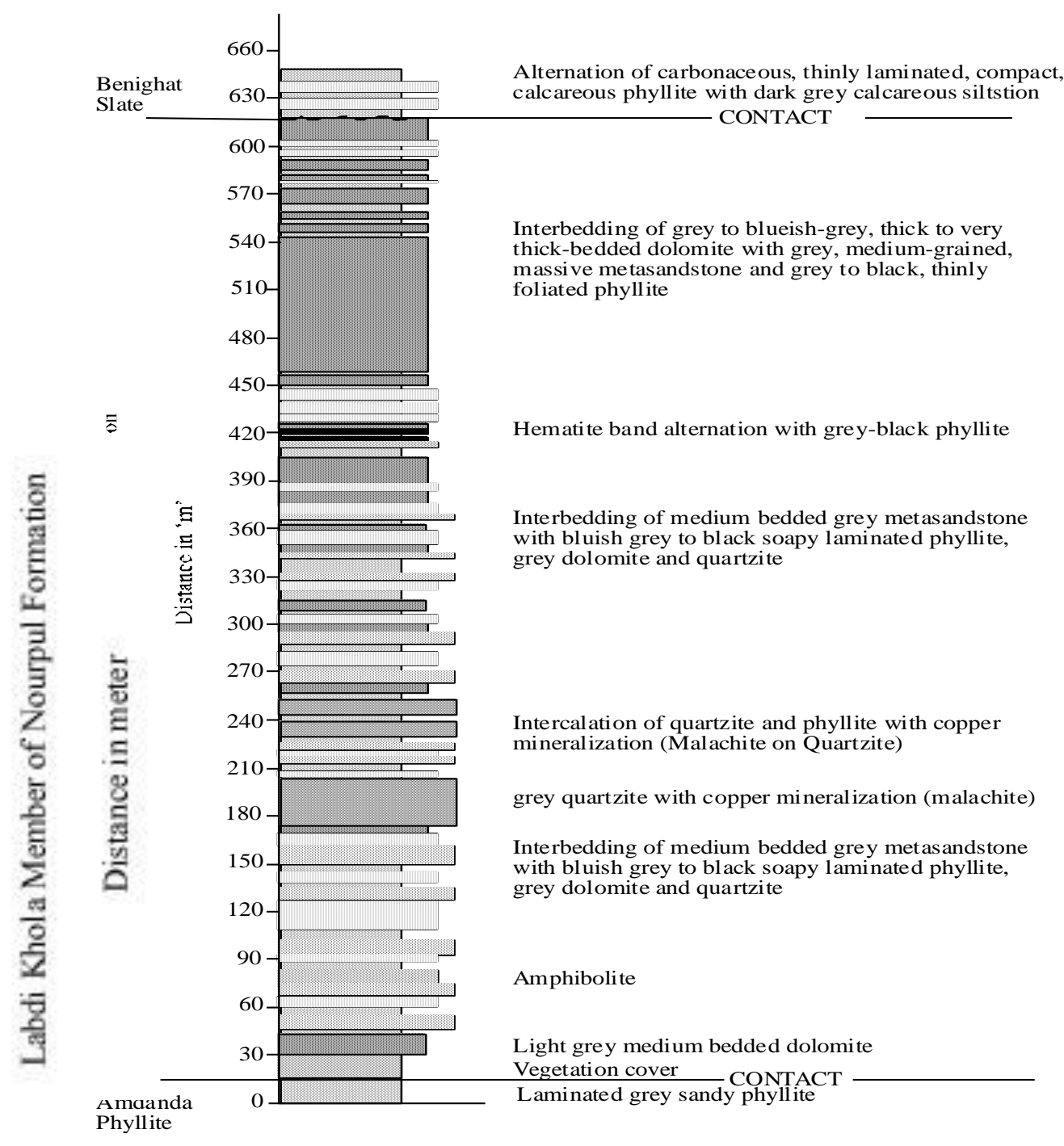

Fig 5 Occurrences of iron deposits in Labdi Khola Member of the Nourpul Formation.

The total thickness is measured $40 \mathrm{~m}$ in stream section. It has very good extension (at least $3.0 \mathrm{~km}$.) and has almost E-W strike.

Both polished and thin sections were prepared for its mineralogical content. About $90 \%$ of the sample contains actinolite, tremolite and chlorite with some quartz. The significant quartz is due to metamorphic reaction of amphibolites and pyroxene group of minerals. Remaining $10 \%$ consists of metallic content as pyrite, chalcopyrite and cuprite with some brilliant content (suspected gold?). Some fine golden fragments or grains observed in one thousand magnifications after treatment with hot nitric acid supported the possible presence of gold.
Presence of more than $40 \%$ actinolite is the cause of green color in rock mass. It gives good shiny luster on gentle polish. Therefore, it can be used as green marble for flooring and decoration purposes. Petrologically, it is the metamorphic equivalent of diorite or gabbro or basalt.

Bar Khola - Jaubari Khola Carbon Deposit: The right hills of Seti Nadi are rich in charcoal black graphitic slate (good economic source of carbon). The deposit is very huge - occupying the total streams and ridges monotonously (more than 90\%). It is associated with finely foliated carbonaceous slate (Fig 7) which is equivalent to the Benighat Slates in central Nepal. Two distinct horizons 
(within the total carbonaceous slate) of total thickness $100 \mathrm{~m}$ is well exposed at Bar Khola and Jaubari Khola. Although the carbon content is high, degree of graphitization is very weak as per the XRD data. The total strike length of the carbon rich strata is about $4,000 \mathrm{~m}$ (adding two parallel bands) and average thickness is calculated as $500 \mathrm{~m}$ while summing the three different horizons (Fig 2). Somewhere, the black carbonaceous slate is also consisting of gypsum veins and occasionally polymetallic deposits. Gold and some rare elements are suspected to be associated with poly-metals.

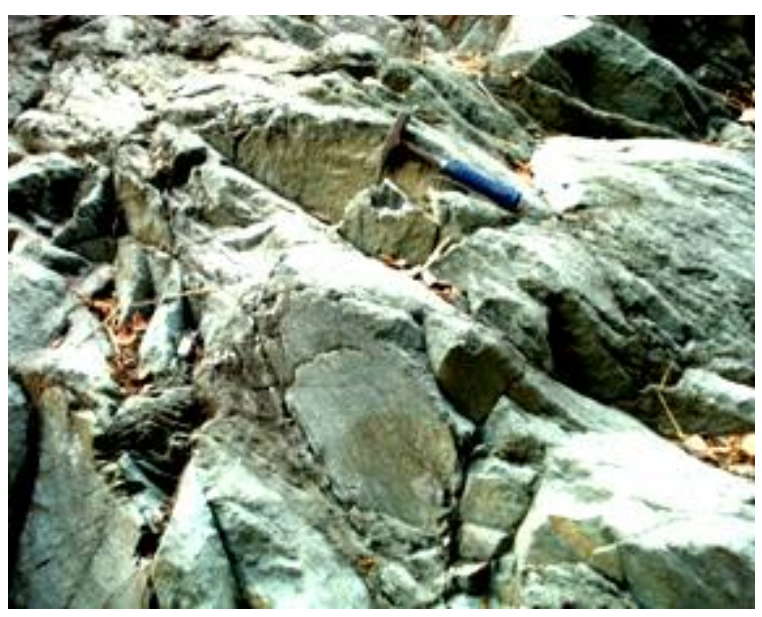

Fig 6 Outcrop view of green marble (amphibolites) exposed in Bagar Khola section, about $7 \mathrm{~km}$ south west of Ghu maune to Damauli road.

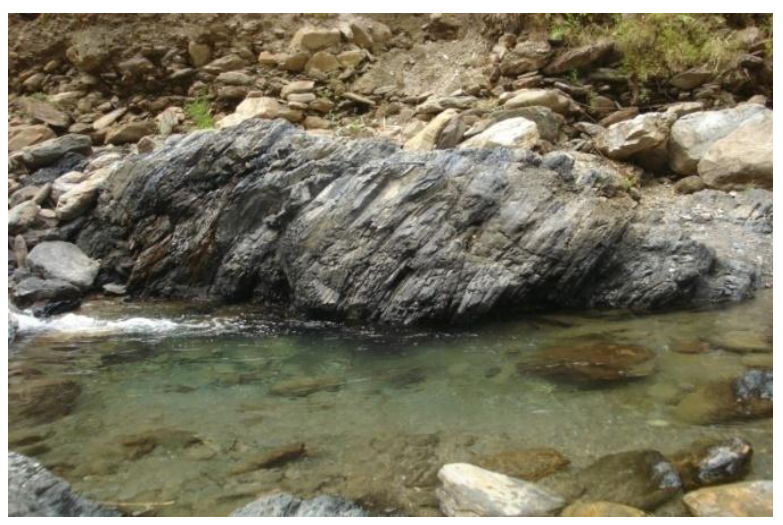

Fig 7 Outcrop view of graphite/carbon deposit at the right bank of Bar Khola about 500m upstream from the confluence of Seti and Bar Khola

To assess the type of carbon (whether it is carbon or graphite), X-ray Diffractrometry Analysis is carried out (Fig 8). Short elevated curve represents X-ray Diffractrometry result of the Bar Khola carbon deposit, whereas the tallest peak represents the pencil graphite (standard graphite). The curves are shown to compare the graphitization with pencil graphite which is the standard one. The result shows that the carbon is not graphitized. The deposit can be used as carbon only since the carbon has many industrial uses.

Both thin section and polished section of the carbonaceous slate were prepared to find the percentage of carbon in the rock. Study of these sections shows about $58 \%$ carbonaceous materials in the sample (Fig 9). This is good percentage of carbon. It means the carbon content of the material can be used in painting and for other industrial uses.

Hilekharka Copper Deposit: Two old copper mining adits are observed in Tallo Hilekharka (Raniban area) at elevation of $1,100 \mathrm{~m}$. Green mineralization on pellitic phyllite is fairly distinct around the adit. No more information is found about the historic mines in literatures. Faint green and blue coloration are also observed on the surrounding area as an indicator of copper mineralization. The main host lithology consists of the succession of pellitic Phyllite (80\%) and Ortho-quartzite (20\%). The Quartzite is dirty grey and ferruginous. Boudinages of quartzite are found within the incompetent beds of Phyllite. Present observation shows noneconomic pocket deposit of copper without any significant extension within the area. Copper mineralization is possibly due to some local geological structure. Geologically, it is in the transitional contact of Purebesi Quartzite and Dadagaon Phyllite.

Hilekharka Geru Deposit: About $15 \mathrm{~m} \times 50 \mathrm{~m}$ exposure of well developed Geru (it is Nepali name for orange like color soil) is observed at the lower reaches of Geru-kholagau ( in topomap it has been named Merukholagau mistakenly), at the elevation of $1150 \mathrm{~m}$, south west of Hilekharka. The host rock of Geru is ortho-quartzite, which shows light ash 


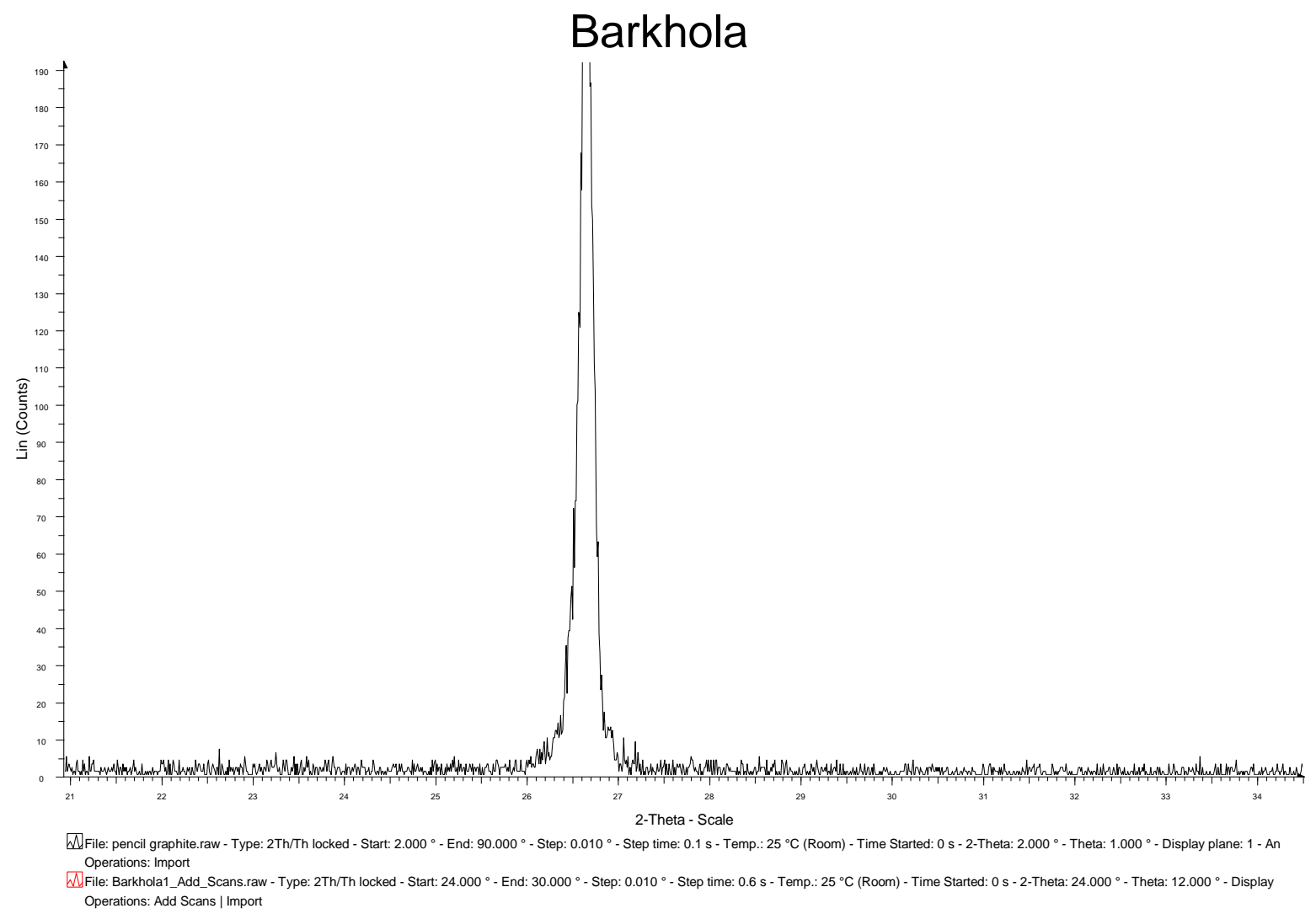

Fig 8 X-ray Diffractogram of the carbonaceous s late of Bar Khola area (low elevated curve) and pencil graphite (high elevated curve).

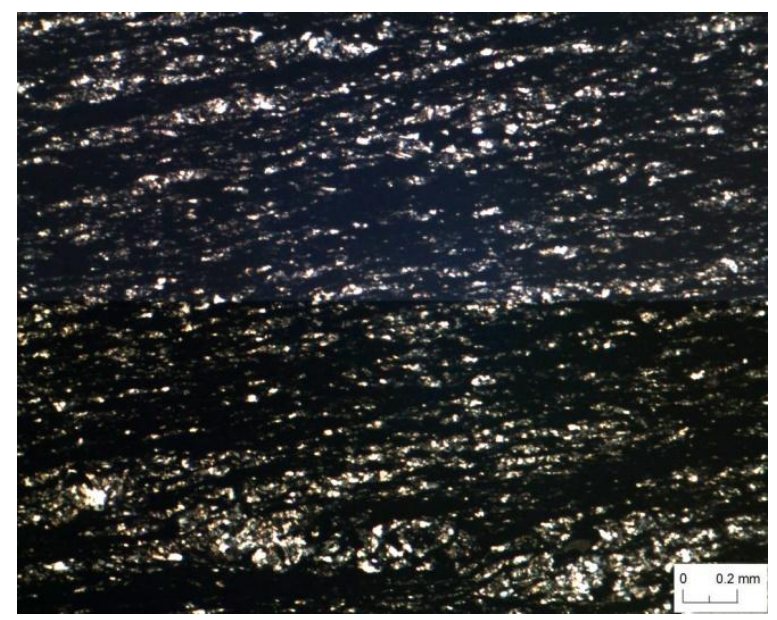

Fig 9 Photomic rograph $(4 \times 10)$ of the carbonaceous slate of the Benighat Slates in Bar Khola Section, showing the proportion of the carbon.

grey in fresh and distinct Geru in weathered condition (Fig 6). The deposit might be an indicator of mercury, cobalt, nickel or other heavy or rare elements in addition to good quality of Geru. The total strike length of the geru bearing strata is about $500 \mathrm{~m}$ with thickness about $100 \mathrm{~m}$.

Musti Khola Iron Deposit: A pocket deposit of iron is reported at the left bank of Musti Khola about $650 \mathrm{~m}$ north from Agetar (toposheet of Demre-Bandipur). The thickness of the deposit is $6 \mathrm{~m}$; however the strike length is very short (about $50 \mathrm{~m})$ with $6 \mathrm{~m}$ thickness. So the iron could not be traced out along its strike. Based on physical properties, it is non-economic and of low quality limonite deposit within the host rock of metasandstone and ortho-quartzite of Nourpul Formation. Based on its physical properties and its density, about $40 \%$ of iron can be estimated.

Bandipur Slates: It is well developed at Bandipur and its adjacent areas. The rock succession consists 
of the monotonous grey, faintly laminated slates with subordinates of grey, coarse grained, medium bedded meta-sandstones (Fig 12). The thickness of individual sheets of the slates is measured in the range of millimeter to few centimeters. In most of cases the bedding is found parallel to the foliation or cleavages. The meta-sandstones are found grey, medium grained with cross laminations. The metasandstones in some palaces show the growth of small well developed rock crystals. It is mapped as the top most unit of the Nourpul Formation. The slate at and around Bandipur area is found good roofing quality. It is dark grey to black in fresh, whereas silvery white to ash grey in weathered condition.

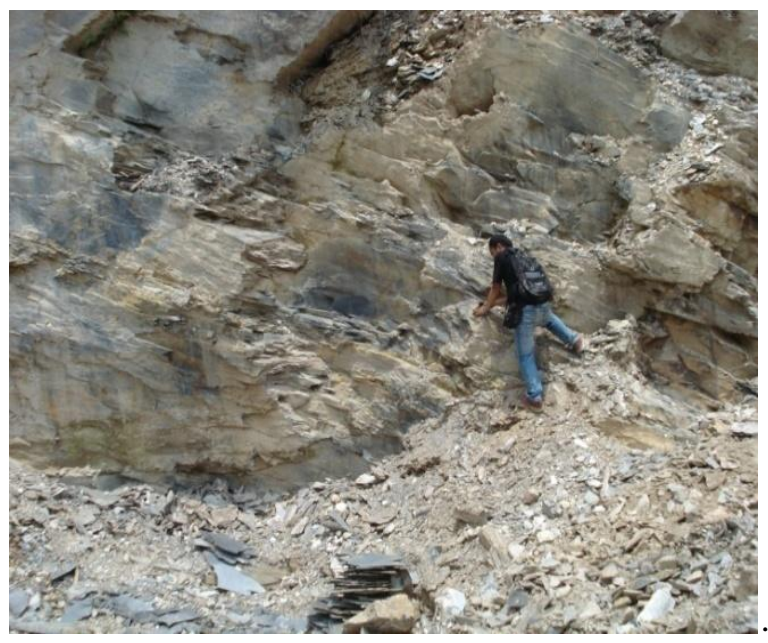

Fig 12 Outcrop view of Bandipur Slate observed at the lower reaches of Bandipur Bazzar, near Jhapri.

\section{Geological Control of Mineralization}

The study area is rich in both metallic as well as non-metallic mineral deposits. Most of the mineral resources are found within the Nourpul Formation and some within the Benighat Slates. At the contact of the Nourpul and the Dhading Dolomite, iron mineralization is mapped (Phalamdada limonite deposit). The extension of iron ore is controlled by the geological contact of these two rock formations. In Phalamdada area, an outlier of dolomite has been mapped (Fig 2). Dolomite contains abundant stromatolites indicating shallow marine depositional basin. Iron deposit in contact hence represents the sedimentary origin of deposition. Most probably, it was deposited in intermediate depth by precipitation from solution under bacterial action.

Iron mineralization is traced out around the ring of outlier, however, the grade and thickness of iron deposit are not uniform throughout the ring of the outlier.

At Bhangeri Khola, polymetallic deposit is found with traces of suspected gold in association with pyrite, chalcopyrite, magnetite, arsenopyrite and cuprite. Locally developed slate within the Nourpul Formation is the potential lithology for polymtallic deposits. The host rock consisting of polymetallic deposit is also rich for graphite or carbon. It is vein type polymetallic deposit (width of vein varies from few centimeter to micrometer). Metals containing veins are found structurally controlled. Veins are inter-fingering within black slate and found parallel to foliation. These hydrothermal veins are considered the possible targets for precious minerals, like gold.

Green Marble quality amphibolites (metabasite) are extensively mapped in Bagar Khola section. Geologically, it is mapped as the top part of the Nourpul Formation. It is the metamorphic equivalent of gabbro or dolerite. The contact of the green marble is conformable with country rocks. It indicates the syngenetic evolution of green marble with the country rocks. In the beginning, it probably evolved as gabbro or basalt, and after metamorphism it is in the form of amphibolite. It is light green in color and coarsely crystalline. The green color is due to the presence of green prismatic crystals of hornblende and acicular minerals, like actinolite and chlorite. Some parts of the deposit are found as green schist after retrograde metamorphism.

Bar Khola Carbon Deposit is widespread in the present study area (right bank hills of Seti Nadi). A thick monotonous succession of black slate/phyllite is mapped around the Bar Khola, Jaubari Khola, Gondrang and Watak areas; however, the economic deposit of carbon is found only in two horizons (Fig 
2.0). The succession is mapped as the equivalent of Benighat Slates in central Nepal. During metamorphism carbon deposit changes into crystalline graphite. Therefore, there is possibility of graphite in certain bands; however, the sampled material is found to be carbon not graphite. The carbon deposit is found abundant and hence can be considered economic. Gypsum deposits (vein type) are also found within the charcoal black folded slate in Bhut Khola, Bar Khola, Jaubari Khola and its adjacent areas.

Bhangeri Khola polymetallic deposit is hosted in the black slates developed within the middle part of Nourpul Formation in Bhangeri village. The quartz veins found in these slates are rich in suspected gold and other associated polymetals. The veins are the secondary structures developed in the rocks due to hydrothermal activity in the area.

Green marble (metabasite) is located at the top part of the Nourpul Formation. The contact relation with country rocks is almost parallel i.e. conformable. It indicates the syngenetic evolution of green marble with the country rocks. In the beginning, it probably evolved as gabbro or basalt and after metamorphism it is in the form of amphibolite. The green color is due to the presence of green prismatic crystals of hornblende and acicular actinolite and chlorites.

Carbon deposits within the Benighat Slates is prominet in the area. It is inorganic carbon with slate host. Slates are considered the deposits of deep basin from suspension load of the rivers. In the same time, the inorganic carbon also deposited as the dominent mass which is in the process of graphitization due to metamorphism.

\section{Discussion}

Based on the present geological mapping and analys is of grab sampling, the following discussions can be made.

1. Iron deposit of Phalamdada area can be considered economic, and further detail reserve calculations are necessary with drilling data.
Since the deposit is in the form of ring around the outlier of dolomite, the size of dolomite is small, and an open cast mining can be performed with the concept of zero waste mining utilizing dolomite as an industrial mineral.

2. The polymetallic vein deposit of Bhangeri Khola is found hosted in charcoal black slate. The widespread extension and distribution of such host rock indicates its economic distribution with suspected gold and other valuable metals; however, the detail laboratory analys is is required on the samples from regular grid system. Present study shows the other valuable mineral like bismuth, silver, etc in addition to gold in the host rock. To assess its economic value, at least 15 samples are necessary to test. The host rock is itself very black and lustrous, which may be an indicator of economic deposit of carbon/graphite. Based on present study, the whole mass might be used after mining and processing.

3. Green marble is found extensive and thick in the study area. Its reserve is sufficient for exploitation. It is precious marble due to its green color and crystalline nature. The grade of weathering is low and blocky in nature. It is non calcareous in nature, i.e. no acid can react with it easily. Based on present field and petrographic study, the deposit is very suitable for green marble as flooring slab. Strength, fracture and polishing tests are recommended for its further confirmation.

4. The right bank hills of Seti River are rich in its carbon or graphite deposits, in addition to some polymetallic veins. The reserve is enough in terms of quantity and distribution. Quantity of carbon is expected more than that is mentioned in this report. Therefore, further steps can be taken for its economic extraction. For that at least 20 samples are recommended to test its carbon content from different locations and grids. Present study also shows the possibility of some valuable minerals like gold and silver within the particular bands of slates having abundant polymetallic veins. Therefore, chemical analysis of the sample is recommended to assess its valuable content. 


\section{Conclusion}

The following conclusions are drawn from the present study:

1. The study area is rich in both metallic and nonmetallic deposits.

2. The possible economic minerals in the area are: Phalamdada Limonite Deposit, Labdi Khola Iron, Bhut Khola Copper Deposit, Green Marble (amphibolites) of Bagar KholaDharampani area, Bhangeri Khola Polymetallic Deposit, Bar Khola- Jaubari Khola Carbon Deposit and Bar-Jaubari Khola Polymetallic Deposit.

3. The other possible economic minerals of the area can be mentioned as: Jhargaon green fluorite and rock crystal, Hilekharka Geru Deposit, Bar Khola-Jaubari Khola gypsum veins, Giranchaur Dolomite and Jal Bhanjyang Ortho-quartzite. No detailed study is carried out on these minerals in terms of their quantity and quality. However, these minerals are shown in the geological map of the area.

4. The geological relation of mineralization can be categorized into two parts: structural and stratigraphic controls. Bhangeri Khola Polymetallic Deposit with suspected gold is due to structural control associated with hydrothermal quartz veins. Bhut Khola copper is related to the basic magmatism. The Labdi Khola iron is syngenetic with the adjacent rocks of Labdi Khola Member of the Nourpul Formation.

5. Laboratory test of graphite, and study of collected rock samples under polished and thin sections shows that the Bar khola-Watak graphite is of carbon grade. It consists of about $58 \%$ carbon and due to high percentage of carbon in the rock, it can be used for different industrial purposes. The polymetallic deposits within the black slates equivalent to the Benighat Slates of central Nepal are evaluated to be precious due to suspected gold. Green marble (metabasite) of Bagar Khola area takes good polish and it is green in color due to significant presence of chlorite, actinolite and tremolite minerals which make it have decorative value.

\section{Acknowledgement}

This work is a part of Ph.D. research of author. I am thankful to Nepal Academy of Science and Technology (NAST) for Ph.D. grant. I express my sincere gratitude to the Central Department of Geology, Tribhuvan University for providing the laboratory facilities. I am thankful to Dr. Lalu Paudel, Head, Central Department of Geology for the critical comments and suggestions to prepare this paper. I am also thankful to one unknown reviewer for his/her valuable comments. I extend my thanks to Mr. Roshan Koirala, Mr. Naresh Maharjan, Mr. Deo Kumar Limbu, Mr. Lok Bijaya Adhikari, and Mr. Pramod Pandey for accompaining in the field work

\section{References}

[1] DMG 2004. Mineral Resources of Nepal. Department of Mines and Geology, Ministry of Industry, Government of Nepal, P 154.

[2] O' Rourke, J.E., 1958. Bandipur slate deposit, Pokhara province, 3pp. Mimeo. Report available in Department of Mines and Geology, Lainchaur, Kathmandu, Nepal.

[3] O' Rourke, J.E., 1959. Mineral discoveries in Nepal. 5pp, Mimeo. Report available in Department of Mines and Geology, Lainchaur, Kathmandu, Nepal.

[4] O' Rourke, J.E., and D.N. Rimal 1959. Dalagaon copper prospect, Bandipur district Nepal, Nepal. 2pp (unpublished report available in the library of Department of Mines and Geology, Lainchaur, Kathmandu, Nepal).

[5] Paudel, L.P., Arita, K., 2000. Tectonic and polymetamorphic history of the Lesser Himalaya in central

[6] Nepal. Journal of Asian Earth Sciences 18, 561-584, 2000.

[7] Paudyal K.R. and Paudel L.P., 2011. Geological setting and lithostratigraphy of the Lesser Himalay a in the Muglin-Banspani area, central Nepal: jour. Nepal Geological Society. Vol, 42, p 51-63.

[8] Paudyal K.R., Adhikari L.B., Maharjan N., and Paudel L.P. 2012. Geological setting and lithostratigraphy of Bandipur-Gondrang area of Lesser Himalaya, Central Nepal. Bulletin of the Department of Geology, vol. 15, p 49-62. 
[9] Sharma, C.K. 1990. Geology of Nepal Himalay a and adjacent countries; Sangita publication, Kathmandu, Nepal; p 470.

[10] Sharma, C.K. 1995. Mineral Resources of Nepal. Published by Sangita Sharma, Bishalnagar, and printed by Printing support Pvt. Ltd. P. O. Box 1217, Kathmandu, Nepal; p 142.

[11] Stöcklin, J., 1980, Geology of the Nepal and its Regional Frame: Journal of the Geological Society of London, V. 137, pp. 1-34.
[12] Stöcklin, J; Bhattarai, K.D., 1977. In: Himalaya Report Geology of Kathmandu Area and Central Mahabharat Range Nepal. Department of Mines and Geology Kathmandu, Nepal, 86 pp.

[13] Talalov, V.A. 1972. Geology and Ores of Nepal. 4 volumes (unpublished) Nepal Geological Survey Kathmandu (available at the library of Department of Mines and Geology, Lainchaur, Kathmandu, Nepal).

[14] United Nations 1993. Geology and Mineral Resources of Nepal vol.9UN, Economic and Social Commission for Asia and the Pacific (ESCAP) and Department of Mines and Geology (DMG); pp 107. 